Summer 2005

\title{
Bioethics and Law: Between Values and Rules
}

\author{
Cinzia Piciocchi \\ University of Law-Trento, Italy
}

Follow this and additional works at: https://www.repository.law.indiana.edu/ijgls

Part of the International Law Commons, Legal Ethics and Professional Responsibility Commons, Legislation Commons, and the Science and Technology Law Commons

\section{Recommended Citation}

Piciocchi, Cinzia (2005) "Bioethics and Law: Between Values and Rules," Indiana Journal of Global Legal Studies: Vol. 12 : Iss. 2 , Article 6.

Available at: https://www.repository.law.indiana.edu/ijgls/vol12/iss2/6

This Symposium is brought to you for free and open access by the Law School Journals at Digital Repository @ Maurer Law. It has been accepted for inclusion in Indiana Journal of Global Legal Studies by an authorized editor of Digital Repository @ Maurer Law. For more information, please contact rvaughan@indiana.edu.

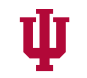

JEROME HALL LAW LIBRARY

INDIANA UNIVERSITY

Maurer School of Law
Bloomington 


\title{
Bioethics and Law: Between Values and Rules
}

\author{
Cinzia Piciocchi*
}

\section{INTRODUCTION}

The scientific progress of the last thirty years has opened up new doors in many different fields, such as reproduction (for example, in vitro fertilization and cloning), organ transplants, sexuality, and others.

This incredible scientific progress has had a significant social consequence: facts turned into choices. What in the past simply happened, has become a possibility that may be chosen by individuals. The boundaries of existence, its beginning and its end, are less precise, making more and more room for individual choice. With respect to the beginning of life, parents can learn whether their children carry genetic defects, and as a consequence, they can choose whether to bring them into the world, and if the embryos are the result of in vitro fertilization, the parents may even select which embryos to implant.

Similarly, the end of life is no longer totally beyond an individual's control. Scientific progress prolongs the last part of human existence. In many cases, death does not simply happen: it becomes a process in which the choice, and as a consequence the will, of individuals plays a crucial role.

These are only two examples that nevertheless highlight the legal consequence of this change: regulating personal choice is undoubtedly more difficult than regulating facts.

At first sight, the reaction of many legal frameworks to this incredibly rapid scientific progress has been to allow absolute freedom. Many fields have been characterized by a lack of rules, or at least by the stratification of an inconsistent regulatory system. It may be wrong to describe this phenomenon as a conscious choice by legal systems, at least in the initial phase; rather, it was the result of a shock. It was the shock of individuals facing the possibility of making choices about their own existence and the shock of societies facing newly broadened horizons. It was a shock to political frameworks, which had to deal with ethical dilemmas and with the uncontrollable quickness of new scientific discoveries. Finally, it was a shock to lawyers because scientific progress changed the basis of their "tool kits."

Not only have the legal rules had to face the role of individual choice con-

*Research Fellow in Comparative Public Law, University of Law-Trento, Italy. 
cerning the basic aspects of human existence (reproduction, sexuality, etc.), but they more often have had to face the moral values that underlie those choices.

When freedom started to resemble anarchy, the need for rules emerged, but it clashed with a reflection about the role of law, especially with regard to ethical pluralism. Going back to the law also meant having second thoughts on the role of law itself. The adoption of regulations in the fields of biomedicine and bioethics has met many obstacles. For example, rules need (at least) a minimal level of consensus, as well as time, in order to be approved. It is extremely difficult to comply with both of these needs.

The analyses of these problems have led to a new substantive area of law: "biolaw." It is based, in part, on the debate about the role of the law (especially with regard to statutory law) facing bioethics, and more generally, on the debate about the role of the law itself. This paper tries to explain the main features of this debate.

\section{The Bases of Law are Crumbling: The Fading Away of the "Biological Paradigm"}

If it is true that in the actual scientific framework facts become possibilities, it may be useful to give some examples. The incredible scientific advancements of the last several years have posed two main problems: on the one hand, individuals are facing the difficulty of making choices, while on the other hand, legal systems have to debate facts turning into possibilities and the changing of the biological reality that many legal rules were based on.

In the past, birth was described with certainty with a series of facts, which may be defined as the "biological paradigm."2 In other words, the beginning of

1. See Laura Palazzani, Introduzione alla biogiuridica 54 (2002) (explaining that the Italian biodiritto is translated in English as biolaw, in French as bio-droit, and in Spanish as biojurídica).

2. See, e.g., B.L. Wilder, Assisted Reproduction Technology: Trends and Suggestions for the Developing Law, 18 J. Am. Acad. Matrim. Law 177 (2002).

I have suggested elsewhere, and do so again here, that we abandon use of the biological paradigm to establish the parent-child relationship, in favor of a legally significant acts paradigm. That is not to say that biological relationships are irrelevant in the determination of parental and child rights, but it is to say that such relationships should be thought of as evidence of certain legally significant acts that, among others, establish the parent-child relationship, as opposed to being dispositive per se, with the occasional (and in the area of ART law, increasingly frequent) exception.

Id. 
existence was described by an indefectible biological reality: a sexual relation, between male and female, whose gametes gave rise to fertilization. These were not choices; these were facts on which the legal regulations of parental relations were based. Again, the recent scientific progress turned these facts into choices. The first "attack" on the "biological paradigm" came from assisted reproduction technology. A possible outcome of the fading away of this paradigm emerged: the lack of protection for some subjects, especially children.

This was highlighted by cases regarding the disavowal of paternity that arose in both the Italian and French legal systems. In both of these legal systems, the idea of a child conceived with the intervention of a third party outside wedlock was unavoidably associated with adultery. Consequently, the father might act for the disavowal of paternity. But with in vitro fertilization, if a donor intervenes, the biological parents may never meet, and the presence of a third person outside wedlock does not equate with adultery.

Both the French and Italian legal systems had to face many cases of fathers who had previously consented to donor insemination, but subsequently changed their mind, acting for the disavowal of paternity. At first, the courts simply applied the existing law giving priority to the "biological paradigm," but in cases like these the assumptions were completely different. Nevertheless, in many circumstances this strict application of the law assured the success of the disavowal of paternity.

Both legal systems adopted laws explicitly forbidding an action to disavow paternity in cases like these. In 1994, the French loi de bioéthique provided a precise procedure for donor insemination. ${ }^{3}$ On the one side, it excluded every link between the "biological father" and the child conceived with this technique and, on the other, it provided a precise procedure to consent to this kind of technique.

In 2004, the recent (and controversial) Italian law on assisted procreation expressly prohibited donor insemination. ${ }^{4}$ In addition, even if this provision is infringed, it expressly provides that parents cannot disclaim the paternity (or maternity) of the child. ${ }^{5}$

However, both the French and the Italian courts had already outlined the new features of the "biological paradigm" before the legislatures intervened. For example, in 1998, a decision of the Italian Constitutional Court stated that in the

3. Law No. 94-653 of July 29, 1994, J.O., July 30, 1994, p. 11056 (Fr.).

4. Norme in Materia di Procreazione Medicalmente Assistita, art. 4, Law No. 40 of Feb. 19, 2004, Gazz. Uff., Feb. 24, 2004 (It.).

5. Id. art. 9. 
case of donor insemination it was not possible to act for the disavowal of paternity, such action being based, according to the Court, on grounds completely unrelated to the factual situation of this particular kind of in vitro fertilization. ${ }^{6}$

A famous decision of a French court went even further. It claimed that biological reality has changed and that there is another element to be considered in the field of reproduction: the will of parents. In other words, the court was aware of the importance of the choice of parents (in this case the choice to conceive a child with the intervention of a third-party donor) and gave it legal relevance. ${ }^{7}$

Similar problems will develop in the future as the other elements of the "biological paradigm" fade away. For example, with the recent development of cloning techniques that allow reproduction without fertilization, even the participation of a both a man and a woman is unnecessary. At this time, all these possibilities are hypothetical, since it seems that none of these cloning techniques has been applied to human beings. ${ }^{8}$

Nevertheless, recent British cases show the weakness of legal rules that are still based on the idea that fertilization cannot be disregarded in the legal definition of the beginning of life. For example, the 1990 Human Fertilisation and Embryology Act, which regulated assisted reproduction in the United Kingdom, was based on the assumption that human beings originate from a process of fertiliza-

6. Corte cost., 22 Sept. 1998, n.347, Foro It. 1998, I, 347.

7. T.G.I. Bobigny, Jan. 18, 1990, D. 1990, 333, C. Labrusse-Riou.

La recherche de la vérité biologique dans un tel cas conduit à une impasse et à une solution contraire à l'intérêt de l'enfant, et ce dans la mesure où la volonté des parents s'est superposée sciemment, et grâce aux techniques scientifiques, au jeu de la filiation légitime tel qu'envisagé par le système légal. Il faut admettre, dans ces conditions, que, dans le droit actuel, la volonté des parents puisse jouer un rôle positif à coté de l'effet de la loi, et en tirer des conséquences.

(The search for the biological truth in a case like this leads to an impasse and to a solution, which is against the interest of the child, insofar as the will of the parents is consciously, and thanks to scientific techniques, superimposed on the legitimate filiation's regulation provided by the legal system. It must be conceded that, under these circumstances, in the present law, the will of parents might play a positive role beside the effects of the law, and deducing its consequences.) (author's translation). See also T.G.I. Paris, Feb. 19, 1985, D. 1986, 223, note Paillet; T.G.I. Paris, Feb. 19, 1985, D. 1986, 59, obs. Huet-Weiller.

8. Scientists are rather skeptical about the Raelians' announcement about the birth of a cloned child. See Annuncio-choc dagli Usa "Nata Eva, prima bimba clonata," La Repubblica, Dec. 27, 2002, at http:/www.repubblica.it/online/scienza_e_tecnologia/embrione/clonaid/clonaid.html (last visited Apr. 1, 2005); see also The Raelian Message, at http://www.rael.org/english/index.html (last visited Apr. 1, 2005) (homepage of the Raelian Movement). 
tion. In 2001 this act was modified in order to allow so-called "therapeutic" cloning, that is, the cloning of human embryos only for therapeutic purposes. The lawsuit of a pro-life alliance drew attention to the fact that, such being the law, the British legal system virtually also allowed so-called "reproductive" cloning of human beings. The courts had to use a broad interpretation of the Human Fertilisation and Embryology Act in order to affirm the prohibition of this technique, ${ }^{9}$ and a statute rapidly followed explicitly banning reproductive cloning. ${ }^{10} \mathrm{As}$ in the French and Italian cases, the courts and the legislature directed their efforts toward the same objective: to fill in the legal gaps in the path of scientific progress.

It is clear that the first outcome of the fading away of the "biological paradigm" was the emergence of the vital role the courts played in these cases. All three cases mentioned above prove this to be true: the Italian, French, and British judicial decisions anticipated some solutions, which were eventually affirmed by statute. ${ }^{11}$

The importance of the courts comes out of common law, as well as civil law, legal systems. However, this is still a kind of "emergency scenario," where the legal systems try to keep abreast of scientific progress. This is an ongoing challenge the law seems to lose every time.

9. See Aurora Plomer, Beyond the HFE Act 1990: The Regulation of Stem Cell Research in the UK, 10 Med. L. Rev. 132, 135 (2002); R. (Quintavalle) v. Secretary of State for Health, 4 All E.R. 1013 (2001); Kathy Liddel, Purposive Interpretation and the March of Genetic Technology, 62 Самmridge L.J. 563 (2003); R. (Quintavalle) v. Secretary of State for Health, 2 All E.R. 625 (2002); R. (Quintavalle) v. Secretary of State for Health, 2 All E.R. 113, 13 (H.L. 2003):

While it is impermissible to ask what Parliament would have done if the facts had been before it, there is one important question which may permissibly be asked: it is whether Parliament, faced with the taxing task of enacting a legislative solution to the difficult religious, moral and scientific issues mentioned above, could rationally have intended to leave live human embryos created by CNR outside the scope of regulation had it known of them as a scientific possibility. There is only one possible answer to this question and it is negative.

Id.; see also Derek Morgan \& Mary Ford, Cell Phoney: Human Cloning After Quintavalle, J. Med. Eтнics, Dec. 2004, at 524, available at http:/jme.bmjjournals.com/cgi/data/28/1/DCl/32 (last visited Apr. 1, 2005).

10. Human Reproductive Cloning Act, 2001, c. 23 (Eng.). "(1) A person who places in a woman a human embryo which has been created otherwise than by fertilisation is guilty of an offence. (2) A person who is guilty of the offence is liable on conviction on indictment to imprisonment for a term not exceeding 10 years or a fine or both."

11. See also Margarita Boladeras, The Interaction Between Law, Science and Society, in Science, Law and the Courts in Europe 99 (Amedeo Santosuosso et al. eds., 2004). 


\section{The Need for Rules: Law... and Pluralism}

When scientific progress became more than a hypothetical matter of discussion within legal frameworks, the serious problems it created turned it into a topic of wide debate. A deep, interdisciplinary reflection was necessary that involved ethics, law, and science. The main outcome of this was the beginning of a new branch of law: "biolaw" (a neologism, which appeared also in other languages). ${ }^{12}$ It originated from a deep consideration not only of the relation between law and bioethics, but also of the role of law itself.

Many of the different models that are proposed have some common ground; nevertheless, three groups may be singled out. The first group includes the "private approach,"13 the "use of social non-regulatory tools,"14 or the "factualsociological model." 15 These definitions describe a certain attitude of law toward bioethics, and they share at least two main features. First, they all describe the role of law as being minor: it merely records social behaviors, without imposing any rule. In other words, law corresponds to what happens, social action. Second, and as a consequence, the private-individual sphere plays a fundamental role in the regulation of these topics: individual conscience and self-regulation standards (e.g., standards of the medical profession) are the main sources of rules.

Going to the "extremes," the attitude of law in this category may be described as Highly Inappropriate Legislation (HIL), which means that law (in this case statutory law) is not the preferable means to regulate (and solve) ethical dilemmas faced by individuals when making a choice regarding their own existence. ${ }^{16}$

On the opposite end of the spectrum is the second group, which includes different approaches as well: the formalistic model, ${ }^{17}$ the legal regulation model, ${ }^{18}$ and the prohibition model..$^{19}$ According to these models, law plays a fundamental role as it must regulate every single aspect of bioethical matters.

12. See Palazzani, supra note 1; Adriano Bompiani et al., Bioetica e diritti dell'uomo nella PROSPETTIVA DEL DiRITTI INTERNAZIONALE COMUNitARIO 20 (2001).

13. See Linda Nielsen, Dalla bioetica alla biolegislazione, in UNA NORMA GIURIDICA PER LA BIOETica 45 (Cosimo Marco Mazzoni ed., 1998).

14. See Marsha Garrison \& Carl E. Schneider, The Law of Bioethics: Individual Autonomy and Social Regulation (2002).

15. See Guy Braibant, Diritto e bioetica, in Questioni di bioetica 325 (Stefano Rodotà ed., 1993).

16. See Nielsen, supra note 13 , at 50 .

17. See Braibant, supra note 15; PaLAZZani, supra note 1, at 64 .

18. See Garrison \& Schneider, supra note 14, at 23.

19. See Nielsen, supra note 13 , at 57. 
Nevertheless, law is not important for what concerns the choice of the ethical and cultural grounds of the legal rules, as it just takes note of the political decisions. The mention of prohibition (in the "prohibition model") derives the main purpose of law from these approaches: law must impose "the" ethical solution, comply with a sole ethical approach, and sanction every departure from it.

In between these two groups there are some intermediate models, differently named (for example, the liberal model), but sharing the idea of a "weak law." A "weak law" protects (and imposes the protection of) some very basic rights; otherwise it provides the procedures to be followed by individuals when they make their choices, without imposing the ethical content that is left to the individuals to determine for themselves. According to these approaches, the law does not adhere to the ethical choice, but it is consistent with different attitudes. However, every one of these models leaves itself open to criticism.

According to the first group, the rules come from a private-individual sphere; thus, an "ethical anarchy" might be the consequence of this model. The second group faces (and solves) both these features, as the role of law cannot be disregarded at all: the democratic and representative debate would bring rules back to democracy. Yet, it may be said that it would solve the democratic deficit ${ }^{20}$ producing a pluralistic deficit at the same time. Singling out the ethical rules, legal systems are likely to leave out every possibility of dialogue with "ethical diversity." On the contrary, pluralism would be guaranteed by the liberal models of the third group, which describe law as a public boundary among different private ethics. ${ }^{21}$

Even this model has laid itself open to criticism, as it may be said that legal systems cannot leave existential choices up to individuals and that the law should clearly point out which choices are "ethically right." Otherwise, many countries have passed from a legal vacuum to the prohibition model. For example, this will be the case for the U.S. legal system with regard to the regulation of human cloning. If the Human Cloning Prohibition Act is approved, it will ban every scientific application of this technique, even with regard to its possible therapeutic applications, namely, "therapeutic cloning." 22 This means that even patients who would find it ethically acceptable to be cured with therapies involving the

20. See Alfred C. Aman, Jr., The Democracy Deficit: Taming Globalization through Law REFORM (2004).

21. Palazzani, supra note 1 , at 61.

22. See, e.g., Human Cloning Prohibition Act, S. 245, 108th Cong. (2003). 
cloning of human embryos (basically with regard to stem cells) will be denied what is sometimes their only "therapeutic hope."

If the law imposes a sole ethical vision, it might not reflect social changes. Euthanasia, considered a crime by the majority of legal systems, is a clear example. The sanctity of life is the value protected by the statutes sanctioning euthanasia as a crime (generally considered as murder). Nevertheless, there has been a half-hearted reaction by the courts, which voiced ethical positions not represented by statutory law. In Canada, for example, many doctors who have assisted their terminally ill patients in committing suicide have not been charged with murder (as provided by the law). Many of them were convicted of "administering a noxious substance" and given probation rather than jail sentences. ${ }^{23}$

The most astonishing case came out of the Italian legal system in 2002, when a court acquitted a man who disconnected the life-sustaining treatments of his dying wife. The court's decision was based on the claimed lack of evidence that the woman was still alive, although she was surely alive some hours before. This was a clear escamotage to strengthen the idea that the behavior of this man was something different from murder. ${ }^{24}$ These Canadian and Italian courts' decisions voiced a different ethical position, not adopted by statutory law.

There is another possible risk of the prohibition model: the distance between the principles it tries to impose, combined with a different social perception, might develop into distance between rules and facts. For example, a recent Italian survey among some doctors revealed that almost 4 percent of them had practiced active euthanasia with their patients. ${ }^{25}$

If the purpose of the law is the protection of the sanctity of human life, sometimes the prohibition model seems to reach a different outcome. One may object that the ethical choice is unavoidable because the law needs at least a minimum level of consensus.

23. See, e.g., Marilynne Seguin, A Gentle Death, ch. 8 (1994), available at http://www. dyingwithdignity.ca/canlaw.html (last visited Apr. 15, 2005) (discussing recent court decisions).

24. See Corte app. Milano, sent. 24, 21-24 Apr. 2002, n.23/02, at 47; see also Carlo Casonato, Morte dignitosa e sospensione delle cure: ordinamenti giuridici a confronto, at http://www.jus. unitn.iv dsg/ricerche/biodiritto/home.html (last visited Apr. 15, 2005).

25. Cf. Adrianno Pessina, La sospensione delle cure in Terapia intensiva: orientamenti, motivazioni e prassi dei medici rianimatori nella città di Milano, at http://www.sibce.iteventi/2002_11_15/pdf/ 07_Giannini.html (last visited Apr. 1, 2005); see also M. de Bac, Il 4\% dei rianimatori pratica l'iniezione letale, Il Corriere della Sera, Nov. 12, 2002. 
In some fields it seems possible to reach a point of contact: as seen above, the refusal of cloning as a means of reproducing human beings is an example of this. Otherwise, in some other fields the consensus simply does not exist and the consequence may be a legal vacuum. For example, the Italian legal system was not able to provide a regulation of assisted reproduction until 2004, when a statute was adopted. The impossibility of reaching a point of contact had a paradoxical outcome: no rules; an absolute freedom; and an "in vitro tourism," which attracted couples to Italy from all over Europe who desired to conceive a child. ${ }^{26}$

\section{Moral Strangers ${ }^{27}$ are Searching for a Common Rule}

The need for dialogue among different cultural groups is not a demand coming only out of the relationship between law and bioethics (here cultural means with culture, religion, philosophy-in other words, the individuals' own weltanschaunn ${ }^{28}$ ). It is a wider problem that regards the role of law by itself, dealing on the one hand with democracy, and on the other hand, with the role of pluralism.

Above, I have explained the first phase of the relation between law and bioethics, the "legal vacuum" that generated the need for rules. Going back to the law, many legal systems opted for the prohibition model, facing the new biological basis of a different scientific reality, but strengthening a sole ethical vision: "the" state's ethical choice that all citizens have to adhere to. The recent Italian law on assisted reproduction gives a clear example. The Italian legal system evolved from a laissez-faire framework ${ }^{29}$ to a prohibition model. The Italian statute adheres to a sole ethical choice, which is clearly aimed at affirming the idea that assisted reproduction must be considered as a last resort, something undesirable. For example, assisted reproduction techniques may be used only in cases of infertility, not to select embryos in order to avoid the transmission of genetic diseases. Moreover, doctors must propose adoption as a possible alternative. ${ }^{30}$

26. See Rory Watson, Focus: Brussels Which “Europe" Should Deal with Ethical Issues?, 308 BRIT. MED. J. 362 (1994).

27. See H. Tristam Engelhardt, Jr., The Foundation of Bioethics (1986).

28. See, e.g., Alexander Schuster, Patrimonio culturale comune, dimensione religiosa e costituzionalismo europeo, in Il processo di costituzionalizzazione dell'unione Europea 237 (Roberto Toniatti \& Francesco Palermo eds., 2004).

29. See Sandra Goldbeck-Wood, Europe Is Divided on Embryo Regulations, 313 BRıT. MEd. J. 512 (1996).

30. Norme in Materia di Procreazione Medicalmente Assistita, art. 6, Law No. 40 of Feb. 19, 2004, Gazz. Uff., Feb. 24, 2004 (It.). 
We still do not know how this law will be interpreted; so far judicial decisions are few. ${ }^{31}$ However, possible outcomes may be foreseen without having to wait for judicial interpretation. Some rules will simply not be enforced, as their symbolic value has been privileged in spite of their effectiveness. This will be the case with the rule, providing that the consent of parents in the assisted reproduction process can be revoked only until the fertilization process begins. ${ }^{32}$ Because the Italian constitutional legal system does not permit an embryo to be placed in a woman without her consent, this rule will not be effective. The distance between legal rules and "legal facts" also derives from other prohibition models, such as in the field of euthanasia, where the importance of the courts emerged sometimes to the detriment of the certainty of law. This role of the courts, if considered in the more general framework, is not a solution; it is a sign of something that simply is going wrong. ${ }^{33}$ The courts acknowledge an idea of substantive justice, ${ }^{34}$ but it must be remembered that legal scholars have widely speculated about an important feature of law in these fields: it must be possible to actually follow the law, and this is not likely to be if its symbolic value prevails over its applicability. ${ }^{35}$

In the prohibition model the law strengthens a sole ethical position; other moral communities might perceive rules as an imposition, as they will not share the ethical values that lie behind those rules.

Health care professionals also might feel excluded. For example, the choices of doctors according to "science and conscience" are not valued in the area of Italian law on assisted reproduction, and in some cases, it will be difficult for the doctors even to understand what the law requires them to do. Again, if the law provides that parents can revoke their consent only until fertilization occurs, what happens if a mother changes her mind before implantation, but after fertilization? On the one hand, the doctor cannot force a woman to do something

31. See, e.g., Tribunale di Catania-Sezione Prima Civile: Ordinanza 3 maggio 2004, at http:// www.filodiritto.com/notizieaggiornamenti/10maggio2004/TCTlegge40procreazioneassistita.htm (last visited Apr. 15, 2005). This decision has been widely criticized.

32. See Norme in Materia di Procreazione Medicalmente Assistita, supra note 30, art. 6, § 3.

33. See Stefano Rodotà, Modelli culturali e orizzonti della bioetica, in Questioni Di bioetica, supra note 15 , at 430 .

34. For a discussion on the idea of "substantive justice" and the rule of law, see VICKI C. JACKsON \& Mark Tushnet, Comparative Constitutional Law 337 (Robert C. Clark et al. eds., 1999).

35. See Paolo Zatti, Verso un diritto per la bioetica, in UNA NoRMa GIURIDICA Per La BIOETICA, supra note 13 , at 72 . 
she does not consent to, but on the other hand, he cannot freeze or destroy human embryos. ${ }^{36}$

The HIL approach would solve this last problem, as there is much room in its scope for self-regulating standards, however, because it renounces every idea of common ethical ground, people are free to build their own private personal ethics. Further, there is another important aspect to be considered: this model does not protect third parties, such as children, in the case of assisted reproduction.

In the field of biolaw, the idea of a "weak law" seems to be the best way to break this impasse. The criticisms of this "intermediate" model are based on the idea that if the law merely establishes boundaries for different private ethics, it would amount to a minimal ethical standard tout court. Nevertheless, the dialogue among different ethical conceptions does not mean that ethics should not be considered at all, as there may be a minimal level beyond which individuals share only the freedom of their choice. ${ }^{37}$

The search for common rules for different communities in the field of biolaw is peculiar, as existential choices are at stake. It may nevertheless be interesting to notice how similar problems come out of the debate about the coexistence of different cultural (for example, religious or philosophical) communities. Heterogeneity is an undeniable fact in contemporary social contexts. In this changing scenario, many legal scholars look to the concept of a "personal federalism," which is rooted in the nineteenth century and is based on the idea that territorial communities share a common legal ground, while in some fields they are regulated by the rules of their group. Personal criteria preside over the participation in these second kinds of communities, and a certain culture is the distinguishing mark of every group. ${ }^{38}$

Modern revisions of these theories focus on the concept of citizenship, particularly referring to "multicultural citizenship," ${ }^{39}$ and it is extremely interesting

36. See Norme in Materia di Procreazione Medicalmente Assistita, supra note 30, art. 14.

37. For example, a similar freedom of choice is guaranteed to health care professionals by conscientious objection. See, e.g., Emanuele Rossi, Coscienza ed appartenenza nella legislazione e nella giurisprudenza costituzionale; alcune riflessioni, in IsOGGETTI DEL PLURALISMO NELLA GIURISPRUdENZA costituzionale 257 (Roberto Bin \& Cesare Pinelli eds., 1996).

38. See Stéphane Pierré-Caps, La Multination (1995); Yves Plasseraud, Lidentité (2000); Karl Renner, Das Selbstbestimmungsrecht der Nationen in besonderer Anwendung auf Österreich (1918); Bartolome Clavero, Diritto debole: Un manifesto moderatamente federale, Filosofia politica, Apr. 1994, at 3.

39. See, e.g., Will Kymlicka, Multicultural Citizenship (1995); Roberto Toniatti, Multicultural Citizenship and Education, 5 Eur. J. Educ. L. \& PoL'y 37, 37-44 (2001). 
to see how similar concepts emerge in the field of biolaw. Some scholars speak in terms of "bioethic citizenship" as a common link among different moral communities that share some basic values and are free to choose among different moral opportunities that biomedical progress offers to citizens. ${ }^{40}$ Moreover, as personal federalism is the best instrument for different cultures to coexist, the idea of functional biomedical federalism emerges as well. ${ }^{41}$ Both concepts are intended to provide a suitable, ideal place for pluralism in different communities' own cultures (cultural communities) and in their ethical choices (moral communities). This is an ideal place where the protection of some basic rights easily combines with the freedom of choice, and "moral strangers" can have a dialogue. These ideas try to reconcile moral pluralism and the protection of some inviolable rights in an unceasing search for common ground.

Different moral communities may reach a minimum level of consensus about what must be considered unethical. Beyond that minimum level, every "group" may have a different opinion about what is or is not an ethical choice. In this scenario, the role of the law would be "weak," as it would provide the procedure to be followed in order to make choices. The law would only focus on the criteria to be used in order to evaluate whether a choice has been autonomously made without coercion.

In this way, the sense of exclusion some moral communities feel might be mitigated, thus encouraging a sense of common identity. The idea of personal federalism, as applied in the field of bioethics, would be a turning point for some legal systems, such as Italy's. It would require a "cultural revolution," in order to make the (assumed) "prevailing culture" understand that times are changing.

40. See Paolo Martelli, Bioetica, pluralismo morale e futuro della cittadinanza, in Questionı DI BIOETICA, supra note 15, at 5 .

41. Id. at 15 . 